\title{
The Essence of Fostering Inmates in the Penitentiary System
}

\author{
Darmawati $^{1} \quad$ Marwati Riza $^{2} \quad$ Achmad Ruslan $^{2} \quad$ Syamsuddin Muchtar $^{3}$ \\ 1.Doctoral Student, Faculty Of Law, Hasanuddin University, Indonesia \\ 2.Professor Of Law, Faculty Of Law, Hasanuddin University, Indonesia \\ 3.Associate Professor, Faculty Of Law, Hasanuddin University, Indonesia
}

\begin{abstract}
Guidance of inmates becomes a very important thing in the process of law enforcement. Efforts to foster prisoners with a system of rehabilitation and social reintegration will have an impact both on the prisoners themselves and society at large. With a system of rehabilitation and social reintegration, prisoners can return to their original state and return to being responsible members of the community.
\end{abstract}

Keywords: Guidance, Prisoners, Rehabilitation, Social Reintegration, Penitentiary System.

DOI: $10.7176 / J L P G / 94-11$

Publication date: February $29^{\text {th }} 2020$

\section{A. Introduction}

Penitentiary is one of the institutions of the criminal justice sub-system that has a strategic function in the implementation of imprisonment as well as a place for fostering prisoners (hereinafter referred to as WBP) who have committed crimes. The existence of correctional institutions (hereinafter referred to as Lapas) becomes an important thing to foster prisoners so that after undergoing the criminal process in prison, prisoners are aware of their actions and do not repeat the mistakes that have been made and can be accepted again by the community.

Since 1964, the system of guiding prisoners has fundamentally changed from the prison system to a penal system. Likewise, the institution, which was originally called a prison house, was changed to prison according to the Head of the Directorate's Penitentiary Letter No. J.H.G.8 / 506 dated June 17, $1965 .{ }^{1}$

Regulations regarding the implementation of prisoners' guidance are explained in Article 5 Paragraph (1) of the 1945 Constitution of the Republic of Indonesia and set forth in the form of Correctional Law and elaborated through Government Regulation Number 31 of 1999 concerning Guidance and Guidance of Correctional Guidance (hereinafter referred to as PP Guidance and Guidance for WBP) and Regulations Government Number 32 of 1999 concerning Requirements and Procedures for the Implementation of the Rights of Prisoners inmates jo Government Regulation Number 28 of 2006 concerning Amendments to Government Regulation Number 32 of 1999 concerning Terms and Procedures for Implementing Rights of Fostered Citizens jo Government Regulation Number 99 of 2012 concerning Second Amendment of Government Regulation Number 32 of 1999 concerning Requirements and Procedures for the Implementation of the Rights of Prisoners.

Personality coaching is more directed towards mental development and character to be responsible to oneself, family and society. Fostering independence is directed at fostering talents and skills so that prisoners can return to their role as free and responsible members of society.

Philosophically correctional is a criminal system that has moved far away from the philosophy of retributive (retaliation), deterrence (deterrence) and resocialization. In other words, punishment (punishment) is not shown to make suffering as a form of retaliation, it is not intended to make a deterrent with suffering, nor does it assume the convict as someone who lacks socialization. Penitentiary is in line with the philosophy of social reintegration which assumes that crime is a conflict that occurs between the convict and the community. So that punishment (punishment) aims to restore conflict or reunite the convict with his community (reintegration). ${ }^{2}$

Realizing that correcting is a process of fostering prisoners, it is clear that fostering prisoners is the same as healing someone who is temporarily lost because of the weaknesses they have. These weaknesses can be overcome by coaching them.

Philosophically, correctionalism shows a commitment to change the conditions of the convicted through the process of fostering and treating very humanly through the protection of the rights of the convicted. This commitment is contained in the provisions of Article 5 of the Penitentiary Law which states that: The correctional system shall be implemented based on the principles of protection, equality of treatment and service, education, guidance, respect for human dignity and dignity, loss of independence is the only suffering, guaranteeing the right to remain in contact with family. ${ }^{3}$

Seeing the increasingly widespread types of crimes that are extra ordinary crimes, then it is time for the Lapas to conduct correctional revitalization by thinking of specific forms of coaching to prisoners who commit crimes that are extra ordinary crime. Corruption is an extra ordinary crime because criminal acts of corruption tend to be

\footnotetext{
${ }^{1}$ Explanation of Law Number 12 of 1995 Concerning Penitentiary.

${ }^{2}$ Direktorat Jenderal Pemasyarakatan. 2009. Cetak Biru Pembaharuan Pelaksanaan Sistem Pemasyarakatan. Jakarta.

${ }^{3}$ Ibid
} 
committed by those who have high social status, both in terms of their position in work before entering prison, as well as their education and economic level. Corruption is an extraordinary crime because the victims caused by corruption are very large.

Corruption is an extraordinary crime that is often carried out in a planned, systematic manner and damages the joints of national economic life. ${ }^{1}$ Corruption as an extraordinary crime makes the nation not only static, but experiences a significant setback.

Corruption is a major crime that is complex and its eradication cannot be carried out normally, but is prosecuted in extraordinary ways. In addition, corruption is also classified as a white collar crime (white collar crime) because the perpetrators are mostly intellectual people.

The act of corruption is very detrimental to the country's finances or the country's economy and impedes national development, so it must be eradicated in order to create a just and prosperous society based on Pancasila and the 1945 Constitution of the Republic of Indonesia.

Corruption is widespread in the community. Progress continues to increase from year to year, both in the number of cases and the amount of state financial losses. Uncontrolled corruption will be a disaster not only for national economic life, but also for the life of the nation in general. ${ }^{2}$

Considering that corruption is an extraordinary crime and must be dealt with seriously by the government and the community from its prevention to the implementation of fostering corruption inmates in correctional institutions, a precise approach is needed so that what is intended for correctional purposes can be realized.

In addition to criminal fines, one of the types of sentences that can be imposed on corruption perpetrators is imprisonment. The imprisonment is carried out in prison. Sukamiskin Class I Prison Bandung is a special institution appointed to foster corruption inmates even though Sukamiskin Class I Prison Bandung is not fully inhabited by corruption inmates.

Prison is a place to conduct inmates training which sometimes the objectives expected in the correctional process are not achieved optimally. Detaining and fostering corruption convicts who previously had political power and great influence on the government is not an easy thing.

Coaching conducted in prisons should ideally pay attention to prisoners' backgrounds before they enter prison. This is needed in coaching so that maximum results are achieved.

Based on the provisions of Article 12 Paragraph (1) of the Penal Code, it is explained that: ${ }^{3}$

In the context of fostering prisoners in prisons, a classification is carried out on the basis of:

a. age,

b. gender,

c. long time criminal imposed,

d. type of crime, and

e. other criteria according to the needs or development of the guidance.

The process of fostering corruption inmates aims to make prisoners aware of their mistakes, improve themselves and not repeat their criminal acts so that they can play an active role in the development process and can live reasonably as citizens who are good and responsible. Lapas is demanded to be able to return its inhabitants to be good people and be able to live in the middle of normal society, but on the other hand these functions do not work because the residents of Sukamiskin Prison are mostly people who have intellectual abilities above Lapas officers. Prisons do not have specific guidance for guiding corruption inmates, so the implementation of coaching is done to prisoners the same as other prisoners.

Guidance for inmates is a system. As a system, fostering prisoners has several components that work interrelated to achieve a goal. One system that plays a role in the process of fostering inmates is the Correctional Officer. Thus, the implementation of correctional requirements requires professionalism of human resources who will understand well the goals of correctional and how to achieve these goals.

The implementation of a number of coaching activities programs in correctional institutions, especially for corruption inmates will experience obstacles and even not run at all. A corrupt convict cannot possibly be trained to be a welder, cattle rancher, fish farmer and so on because they no longer need such skills. Corruption convicts usually only want the fulfillment of their rights in the form of family visits, legal counsel, personal doctors and clergy. ${ }^{4}$

Obstacles in carrying out training in correctional facilities include quality and quantity problems from correctional officers. The lack of correctional officers and the quality or level of knowledge of correctional officers when confronted with corrupt prisoners is certainly not yet optimal in terms of conducting a coaching process in

\footnotetext{
${ }^{1}$ Arif Suhartono, Said Karim, Marwati Riza. 2019. Criminal Accountability Against Illegal Civil Servant Salary Receipt in Criminal Acts of Corruption. Papua Law Journal. Volume 3 Issue 2 May 2019.

${ }^{2}$ Agus Salim, Aswanto, Muhadar, Syamsuddin Muchtar. 2016. Harmonization Of Inter-Institutional Authority In Eradicate Corruption. International Journal Of Scientific And Technology Research Volume 5, Issue 10, October 2016.

${ }^{3}$ Law Number 12 of 1995 Concerning Penitentiary

${ }^{4}$ Agus Hariadi. 2016. Suatu Dilema Dalam Pembinaan Narapidana Koruptor di Lembaga Pemasyarakatan. Jurnal Legislasi indonesia. Vol.13 No.03. p. 305
} 
prisons. So it is natural that the prisoner guidance program cannot be implemented as programmed by the prison. ${ }^{1}$ In addition, most of the correctional officers have not been supported by the provision of skills in conducting coaching with a humanist approach that can touch the feelings of prisoners and be able to be creative in conducting coaching. ${ }^{2}$ For this reason, this article will discuss in depth the essence of prisoners' guidance in the penal system.

\section{B. Philosophical Aspect}

The philosophical foundation is a regulation that is formed considering the view of life, awareness, and legal ideals that originate from Pancasila and the 1945 Constitution of the Republic of Indonesia. Lapas is a State organ which has a role in the law enforcement process because it is part of the integrated criminal justice sub-system. The role is not only in the Post Adjudication stage but also in the pre-adjudication and adjudication stages. The philosophical values of fostering prisoners must always be based on Pancasila and the 1945 Constitution of the Republic of Indonesia.

Correctional system is an arrangement regarding the direction and boundaries as well as how to guide WBP based on Pancasila which is carried out in an integrated manner between the coaches, who are fostered and the community to improve the quality of WBP so that they are aware of mistakes, improve themselves and do not repeat crimes and can be accepted back into the life of the community. . It can be seen that in the implementation of fostering of prisoners, the coach in this case must be guided by the precepts of Pancasila and make Pancasila as a moral basis or norm because the source of value in the life of society, nation and state is Pancasila. Benchmarks about the behavior of inmates can be seen from the way they act in doing an act where it must refer to the precepts that are in the Pancasila.

In addition, the Preamble of the 1945 Constitution of the Republic of Indonesia in the fourth paragraph reads "Then, rather than that, to form an Indonesian government that protects all Indonesian people and the whole of Indonesian blood and to promote public welfare, develop the life of the nation and participate in carrying out world order. based on independence, eternal peace and social justice ". This cannot be separated from the implementation of the correctional role where the State has an obligation to protect the entire Indonesian Nation, advance the welfare of the people and educate the nation's life.

Efforts in protecting the entire Indonesian nation are manifested through the giving of respect, protection, and fulfillment of the right of everyone to obtain recognition, guarantee, protection, and fair legal certainty and equal treatment before the law as stated in Article 28 D Paragraph (1) The 1945 Constitution of the Republic of Indonesia. Based on these provisions, the implementation of the fostering process within prisons must always be directed to support efforts to protect the right to justice of prisoners.

In the penitentiary system, each WBP has the right to receive guidance and their rights are guaranteed such as the right to practice worship, the right to deal with outsiders, the right to obtain information through print and electronic media, the right to education and so forth.

The birth of the Penitentiary Law emphasized the importance of the treatment of WBP with a social reintegration approach. The approach is seen from a philosophical background that maintains a positive relationship with the community by leaving negative values. The most important element in society in a positive approach is through an approach with the family.

Integration between WBP and the community can only be achieved if in this case Lapas is able to provide the best treatment for WBP. The forms of treatment include, among others, service activities, guidance and guidance which are carried out systematically and continuously by prioritizing the principles of human rights protection possessed by WBP.

Philosophically correctional is a criminal system that has moved very far away from the philosophy of retributive (retaliation), detterence (deterrence) and also resocialization. In other words, the punishment is not intended to make suffering as a form of retaliation, it is not intended to make a deterrent with suffering, and also does not assume the convict as someone who lacks socialization. Penitentiary is in line with the philosophy of social reintegration which assumes crime is a conflict that occurs between the convict and the community. So that punishment is intended to restore conflict or also reunite the convict with the community or reintegration. ${ }^{3}$

The penitentiary system is a series of law enforcement that aims to make WBP aware of its mistakes, improve themselves and not repeat the crime so that it can be re-accepted by the community, can play an active role in development and can live properly as a good and responsible citizen. WBP is essentially as a human being and human resources who must be treated properly and humanely in an integrated coaching system.

The process of fostering WBP in prisons must be able to integrate WBP and maintain a positive relationship with the community. Lapas as a place to conduct guidance for WBP must be able to provide good treatment and service to WBP.

\footnotetext{
${ }^{1}$ Deliana. 2007. Implementasi Ide Individualisasi Pidana Dalam Pelaksanaan Pembinaan Narapidana. Jurnal Hukum Pro Justitia, Vol.25 No.2. p. 105.

${ }^{2}$ Heru Susetyo. 2012. Laporan Tim Pengkaji Hukum Tentang Sistem Pembinaan Narapidana Berdasarkan Prinsip Restorative Justice. Badan Pembinaan Hukum Nasional Kementerian Hukum dan HAM RI. p.5

${ }^{3}$ Direktorat Jenderal Pemasyarakatan. 2009. 40 Tahun Pemasyarakatan. Mengukir Citra Profesionalisme. Jakarta. p 11
} 
In addition, in the process of fostering prisoners, Lapas must provide space for the community and WBP to interact with each other so that they can internalize the values and norms prevailing in the community. Society in this case has the responsibility in achieving the objectives to be achieved in the Penitentiary Act.

Correctional system as a treatment system for WBP which is carried out based on the correctional function which includes services, guidance, social guidance, care, security, and observation by upholding the respect, protection and fulfillment of human rights. The implementation of prisoner guidance system in prisons is based on the principles of: ${ }^{1}$

a) Protection

The guiding principle is the treatment of WBP in order to protect the community from repeating criminal acts committed by WBP, as well as providing skills to the WBP to be useful in the community as a form of protection to create peace in social life and achieve unity of life relationships. This principle refers to a philosophy based on the provisions of Article 28 A of the 1945 Constitution of the Republic of Indonesia which guarantees the right to life of every citizen and preserves his life. The guiding principle refers to two things that animate the coaching process in prisons, namely:

1) Protecting the public from the possibility of a repeat of the criminal acts committed by the WBP. This is in line with the purpose of criminal law, which is protecting the interests of the community from threats or possible criminal acts. Criminalization not only creates protection of the interests of the community and protects the rule of law, but also protects the interests of the residents as useful citizens in the community.

2) Giving life to WBP so that they become useful citizens in the community. This principle is directed towards the realization of independent human beings who are skilled and able to have a livelihood. This is in line with social reintegration in order to achieve unity of life relationships.

b) Equal treatment and service

What is meant by the principle of equality of treatment and service is the provision of the same treatment and service to the WBP or commonly referred to as the principle of non-discrimination.

Discrimination is any restriction, harassment or exclusion that is directly or indirectly based on human differentiation on the basis of religion, ethnicity, race, ethnicity, group, class, social status, economic status, gender, language, political beliefs, which results in reduction, deviation or the elimination of the recognition, implementation or use of human rights and fundamental freedoms in the life of both individuals and collectives in the political, economic, legal, social, cultural and other aspects of life. This principle refers to a philosophy based on the provisions of Article 28I of the 1945 Constitution of the Republic of Indonesia that everyone is free from discriminatory treatment on any basis regardless of ethnicity, race, religion, ethnic group, class, politics. It is associated with penalties that discrimination is not permitted, ie there is no difference in the treatment of WBP in fulfilling their rights in prison.

c) Education and mentoring

The principle of education and guidance is intended that the implementation of education and guidance is carried out based on Pancasila, including the cultivation of family spirit, skills, spiritual education, and opportunities to perform worship. This principle requires that WBP in undergoing the process of social reintegration can become an independent and productive person. This principle is needed in the guidance process to develop the potential possessed by WBP based on their abilities.

d) Respect for human dignity.

This principle is intended that as a person who is lost, WBP must still be treated like humans.

e) Loss of independence is the only suffering.

The purpose of this principle is that WBP must be in prison for a predetermined period of time so that the state has the full opportunity to provide guidance to them. During the process of coaching in prison, WBP still obtained its rights like humans.

This principle is important so that WBP will continue to be provided with their rights like humans. In the sense of the word that civil rights remain protected such as the right to health, food, drinking, clothing, bedding, the right to receive care, skills training, recreation, or sports.

The state must not make the conditions fostered worse than before they were deprived of their independence. In these conditions, prisoners must fill their time by showing repairs and improving themselves as members of the community and should not be alienated.

f) Guaranteed right to stay in touch with family and certain people.

This principle is the only suffering which implies that the state must not make conditions fostered worse before prisoners are deprived of their independence. WBP in these conditions must be fostered and equipped with the aim to improve themselves and improve the quality of WBP as a member of the community and should not be exiled.

${ }^{1}$ Article 5 Law Number 12 of 1995 Concerning Penitentiary 


\section{Juridical Aspect}

In juridical manner, the overall values contained in the Law must not contradict the higher Laws. Every legal norm is considered valid because it is made in a way determined by other norms. Thus, the hierarchical relationship of these legal norms illustrates that a higher legal norm becomes the basis of the validity of the norms it establishes (lower norms). ${ }^{1}$

The 1945 Constitution of the Republic of Indonesia explains that the law must protect the entire Indonesian nation, and the state must be able to create a general welfare, as well as the intellectual life of the nation. The 1945 Constitution of the Republic of Indonesia has contained several basic provisions which are closely related to the implementation of correctional tasks related to citizens and residents, human rights, education and culture.

Article 27 Paragraph (1) states that "All citizens are at the same position in law and government and are obliged to uphold the law and government without exception."

The article explains that every citizen including citizens who are undergoing the process of punishment in prison, has the same position before the law and has an obligation to uphold the law.

With regard to human rights, the 1945 Constitution of the Republic of Indonesia states that:

Article 28A: "Everyone has the right to live and to defend his life and lives."

Article 28C Paragraph (1): "Everyone has the right to develop themselves through the fulfillment of his basic needs, the right to education and benefit from science and technology, arts and culture, in order to improve his quality of life and for the welfare of humanity."

Furthermore, based on the 1945 Constitution of the Republic of Indonesia, every citizen must also get protection for self-respect, family, and property that is his property. Convicted prisoners must be kept away from all forms of torture or degrading treatment as stated in Article 28G of the 1945 Constitution of the Republic of Indonesia.

One of the functions of prisons is a place to provide guidance to inmates. The implementation of prisoners' guidance is what is called 'correctional facilities'. The existence of prisons has a very large role in the implementation of guidance for prisoners. The concept of correctional is not only formulating the goal of punishment but is a guidance system that is oriented towards the individual concerned or existing in the midst of society as a whole.

When viewed from its nature, corruption is one of the crimes that are extra ordinary crime. In addition, according to UNODC that corrupt prisoners are included in the high-risk prisoners' indicators because most of them have the money and power to influence the system in prison. Corruption convicts are special prisoners who need special treatment. A new regulation is needed related to the pattern of fostering convicts of corruption because it is given the characteristics of corruption prisoners who are extra ordinary crime different from other prisoners. The unavailability of special rules that govern this matter has led to the development of corruption convicts experiencing various obstacles. In addition, it is necessary to classify the types of corruption crimes to overcome problems in prison.

The goal of separating corrupt prisoners from other prisoners is more aimed at avoiding gaps between prisoners in the guiding process in prison. In addition, in order for the coaching process to run optimally, a humanist approach to corruption inmates is required.

Guidance and strengthening of correctional arrangements need to be optimized in order to achieve the goal of penalties, namely to provide guidance to prisoners so as not to repeat acts and educate them so that they have skills, therefore revisions are needed in correctional administration. Through this revision, fostering prisoners will be classified into super maximum security prisons, maximum security prisons, medium security prisons and minimum security prisons.

With the classification of prisoners, prisoners will be treated according to their intervention needs, so the coaching programs implemented in the penal engineering implementation unit will have clearer specifications and objectives.

\section{Sociological Aspect}

The development of a dynamic society fosters community awareness of the importance of the implementation of the coaching process within the scope of correctional tasks. The community in this case has hopes for Lapas as an institution that is able to carry out its duties and functions optimally. In addition, the community also hopes that in the process of fostering the WBP, protection and respect for law and human rights is needed because they remember that the WBP needs to be protected and given guidance and guidance as a provision for their lives when they leave prison.

The implementation of correctional tasks within 24 years after the birth of the Correctional Act experienced many rapid developments. This development was marked by the formation of a society that was very critical in

\footnotetext{
${ }^{1}$ Achmad Ruslan. Pidato Pengukuhan Guru Besar Fakultas Hukum Unhas Dalam Buku Kapita Selekta Ilmu Hukum. Edisi I. Makassar. Membumi Publishing. p. 567
} 
expressing various problems that occurred in the process of fostering prisoners as well as the emergence of various types, levels and behaviors of crime, both transnational crime, economic crime, organizer crime, and extra ordinary crime.

As a result of the emergence of various types, levels and behavior of crimes, the implementation of the process of guiding prisoners faces quite severe conditions, ie not all prisoners who are in prison are not touched by the coaching activities. When only relying on institutions, it is difficult for Lapas to carry out the process of fostering prisoners to the fullest due to limitations both in terms of funding, equipment and human resources. In addition, crimes that are extra ordinary crime have different characteristics from other public prisoners. Corruption convicts generally have a higher level of knowledge compared to supervisors in the prison. An extra attention and approach is needed in the process of fostering the prisoner so that what is aspired to in the Penitentiary Act and the expectations of the community can be realized. In this regard, in conducting the process of fostering prisoners who are extra ordinary crime, Lapas is expected to have a clear coaching concept, because prisoners consisting of former officials and have a large influence should be in the coaching process carried out with a humanist approach.

Guidance for inmates is a system that works in synergy in achieving correctional goals. As a system, in the implementation of fostering prisoners consist of coaches, prisoners and the community. The three sub-systems must cooperate with each other in realizing what is aspired in the Penitentiary Law. If one of the sub-systems has problems, it will affect the other system.

Seeing the obstacles in the implementation of the guiding system of corruption prisoners, it is important to formulate a concept about the implementation of guiding corruption inmates so that the purpose of correctional can be realized and meet the expectations of the community.

\section{E. Conclusion}

The nature of fostering prisoners in prison is oriented towards rehabilitation and social reintegration, which means there is a close relationship between prisoners (WBP) and the community and aims to improve the mindset and mentality of prisoners (WBPs) in order to realize mistakes, correct themselves and not repeat acts criminal so that it can be re-accepted in society and can live reasonably as a good and responsible citizen.

\section{References}

Achmad Ruslan. Pidato Pengukuhan Guru Besar Fakultas Hukum Unhas Dalam Buku Kapita Selekta Ilmu Hukum. Edisi I. Makassar. Membumi Publishing.

Achmad Ruslan. 2013. Pembentukan Peraturan Perundang-Undangan di Indonesia. Yogyakarta. Rangkang Education.

Arif Suhartono, Said Karim, Marwati Riza. 2019. Criminal Accountability Against Illegal Civil Servant Salary Receipt in Criminal Acts of Corruption. Papua Law Journal. Volume 3 Issue 2 May 2019.

Agus Salim, Aswanto, Muhadar, Syamsuddin Muchtar. 2016. Harmonization Of Inter-Institutional Authority In Eradicate Corruption. International Journal Of Scientific And Technology Research Volume 5, Issue 10, October 2016.

Agus Hariadi. 2016. Suatu Dilema Dalam Pembinaan Narapidana Koruptor di Lembaga Pemasyarakatan. Jurnal Legislasi indonesia. Vol.13 No.03.

Andi Muhammad Sofyan, Iin Karita Sakharina and Handar Subhandi Bakhtiar. Custody Services of The Human Rights Perspective. Quest Journal. Journal Of Research in Humanities and Social Science, Vol 5 Issue 4 (2017). 48-51

Deliana. 2007. Implementasi Ide Individualisasi Pidana Dalam Pelaksanaan Pembinaan Narapidana. Jurnal Hukum Pro Justitia, Vol.25 No.2.

Direktorat Jenderal Pemasyarakatan. 2009. Cetak Biru Pembaharuan Pelaksanaan Sistem Pemasyarakatan. Jakarta.

Direktorat Jenderal Pemasyarakatan. 2009. 40 Tahun Pemasyarakatan. Mengukir Citra Profesionalisme. Jakarta. Heru Susetyo. 2012. Laporan Tim Pengkaji Hukum Tentang Sistem Pembinaan Narapidana Berdasarkan Prinsip Restorative Justice. Badan Pembinaan Hukum Nasional Kementerian Hukum dan HAM RI.

Law Number 12 of 1995 Concerning Penitentiary. 